\title{
Annamaria Cascetta*
}

iD https://orcid.org/0000-0001-8750-3337

\section{Bodies on stage between presence and absence}

No age equals ours in devoting such massive and articulated attention to the body, leading to a change of gaze ${ }^{1}$, a veritable upheaval. It calls into question the ontological problem of the 'lived body', as a subject-person, the juridical problem of the equality of bodies in the culture of rights, the social and political problem of the categories oppressed and marginalised by the strategies of power, the problem of the body manipulated by the new propaganda techniques, the aesthetic problem of the enhancement of an art as 'action' that goes all the way to the presence of the body of the artist (in the visual arts) or of the performer (in the theatre) who becomes himself a work and a brand more than an external creator and author of the work.

An extensive philosophical and sociological literature (starting from transcendental phenomenology) has sought the foundations of free corporeity and legitimised the rejection of any position that intends to make the body a prison, an instrument, a machine, an object to be exploited, manipulated, debased or offended.

And it is this truth that underlies the proclamation of the equality of bodies in democratic societies.

Contemporary art, and specifically that which has its expressive primum in the body, the theater, has thematised this problem very fully, both by recording and denouncing the negative tendencies that oppose this cultural acquisition, and by presenting on the 'other stage' the artistic experience of the image of the 'lived body', in its attainment of dignity, creativity, freedom and generativity.

I will briefly mention this scenario in the following pages.

* Professor, Università Cattolica "Sacro Cuore” in Milan, Dipartimento di Scienze della Comunicazione e dello Spettacolo and Centro di cultura e di iniziativa teatrale "Mario Apollonio", annamaria.cascetta@unicatt.it

1 A fundamental book on this issue is: J.J. Courtine (sous la direction de), Histoire du corps. 3. Les mutations du regard. Le XX siècle, Paris, Éditions du Seuil, 2006. 


\section{"Certainly it takes courage." ${ }^{2}$ The body violated}

Naked, under the cold and implacable light of the closely focused spotlights, a woman's body is exposed on a circus pedestal. Her bistred eyes gleam in the light, her mouth is like a wound drawn by lipstick, her hair is gathered into two buns which, as has been observed, recall the famous image of Frida Kahlo.

It is a "naked mask" that reveals in a flow of words the total absence of a psychophysical identity reduced to a pronoun: "I", screamed hysterically.

Then begins the monologue of the protagonist's delirium: "Of course it takes courage," she opens up, to throw yourself under a train on a Sunday morning without anyone egging you on the way her father did, frustrated in his confused obsession with Garibaldian heroism, in his macho and sexist fantasies.

And certainly it takes courage for a modest girl, small in size who has a problem in her head and big thighs, to insist on wanting to be free to make herself all by herself, completely in control of herself and to affirm herself. But which freedom and which self? We understand it from the flow of her story. For her, freedom means being determined to bend her body to a project actually driven by advertising and the media. But her body is inadequate for this. Freedom for her means being determined to have electrodes applied by an improvised therapist to her thighs when she was still little more than a child. It means going on an impossible 'do-it-yourself' diet of nothing but apples. Freedom means churning out CVs to 'make it big' in the world of dreams built by magazines and television shows: being in the spotlight, walking on red carpets, having big-shot admirers kissing your back, ministers inviting her on vacation and caliphs taking her on a cruise; giving interviews to famous presenters who 'go steady' with her and take the story to the newspapers, freedom means being recognised in the street and giving autographs.

'Freedom', 'courage', 'resistance', 'sacrifices' are the rhetorical terms of a great story, following each other in the monologue to recount and define her bulimic diet in preparation for a coveted audition for a TV commercial celebrating the anniversary of the unification of Italy that calls for a small and tubby bit player. Terms such as "pity" are applied to the oral sex that she began to perform at school on her disabled, mumbling classmates and that she continues to perform on her current partner, pathetically hoping that he will end up sharing her dreams and giving her affection.

And certainly it takes courage and great pity to 'be a success', to break into the world of her propaganda-induced dreams. Who knows how many they must have done at first, those girls who are a success, "on those, yes, those who count, certain

2 C. Ceresoli, La Merda, Rome, Carlo Gallucci editore, 2017, p. 9. The text, written for the actress Silvia Gallerano, was first performed in 2012; it received many awards including the Fringe First Award for Writing Excellence and The Stage Award 2012 for Acting Excellence (2012). 
men, those men who can make or break, who decide and make the conventions". ${ }^{3}$ So she trained her body, "but we can say that's where I learned to do what is needed on certain occasions, that even if something really grosses you out, you can get used to it". ${ }^{4}$ And this certainly pays off.

So what does this body have to have courage for? What does "pay off" in the end?

In the first instance, the monologue can be included in the sphere of verbal invective, like many others found in the theater of political and civil denunciation, but more in depth, it is mimetically a 'theater of presence', filled with anger and pity, which brings the audience into close contact with the experience of an existence manipulated and violated in the most intimate fibers of its psycho-physical being, all the way up to the hallucination of what the well-known and usual metaphor of common language calls "eating shit". We are in the final intake of excrement after the five days of pigging out to swell "and be who I am. What do they want."5

The device is thematically significant and dramatically effective.

The delusion of coprophagy by a deranged being driven to schizophrenia, the story of a body violated, exploited and annihilated affirms its opposite through the actress's performance. The artist is present with all her powerful and creative physicality and with all the ancestry of a great theatre school.

First of all, there is Beckett. The delirium of coprophagia, with all its icasticity, is nothing other than the materialisation on stage with the effect of a paradox, which, as such, shakes us and makes us think of a metaphor of language. This is what Beckett often does in his plays. Think, for example, of Endgame with the two garbage cans to which the old parents Nagg and Nell are relegated.

The protagonist's body is mutilated here, fixed on the mouth and the thighs.

The stage, moreover, as often in Beckett, makes present and palpable a minimal existence, grasped at the level of non-development to which a perverse strategy nails it. It gives a voice to those who traditionally did not have one, just as Beckett did to pioneering effect in Not I or in Footfalls.

And then there is Testori, another important point of reference in this text, with all the physicality of his speech and with all the suffering of a self unborn or in flight, like the self in of In exitu. "[... ] that's me, me, it's me, me, it's me, it's me, it's me, me, meeeeee," as the protagonist screams. So end the second and third acts of La Merda, with an inhuman scream. But which self? The only self is that of the actress who, with her extraordinary voice, renders the fragments taken from a confused existence.

The voice, therefore. When it is the self of the protagonist that wishes to speak, it is split: one is phony, artificial, with the poses, the pauses, the jargon, the rough

3 Ibidem, p. 21.

4 Ibidem.

5 Ibidem, p. 28. 
affectation of a television school (an updated reminiscence of the monologues of Franca Valeri); the other is bestial, shrieking, fierce; the one is childish and naive, the other surly and crafty.

The flow is full, in its turn, of vocal masks and it switches from one to the other: hoarse and distant that of the lady of the homely wellness centre smelling of soup; harsh and aggressive that of her father; deaf and plaintive that of the disabled person who wants sex; impersonal and hasty that of the audition secretary; contemptuous and bored that of the stage director responsible for hiring actors; foul-mouthed and mocking those of the audition technicians.

The work is a masterpiece of actorly energy and intelligence, a strong psychophysical subjectivity to represent a subjectivity ruined by an irreversible corruption, even subtler and more threatening than that represented by Testori's In exitu, where there was the glimmer of a salvific way out for the young drug addict Gino Riboldi. But this Testorian passage belongs to a generation before that of the protagonist of La Merda and to two and more generations from the unforgettable and prophetic cinematic images that announced the theme in the fifties, without obviously forgetting Pasolini. Think of Luchino Visconti's Bellissima or Antonio Pietrangeli's Io la conoscevo bene.

While interpreting a violated and petrified body, the actor nevertheless expresses a free and creative corporeality. This is the dominant sign of many examples of theater in our times, in the area of dance-theater and performance theater, ${ }^{6}$ and is the pars construens of an alarming diagnosis that seeks a renascent horizon in art.

\section{The presence of the absent body}

I spoke of a violated body, but the most 'scandalous' violation of the body, which no one escapes, is death.

What remains of the body? I mean not just the organism (Körper), but its life (Leib). How can it relate to memory and oblivion?

The contemporary experimental theatre has come to face this aspect, too, mimetically and it is an extreme aspect in terms of both existence and its representability, as Tadeusz Kantor prompted us to think.

For my brief reflection on this point I have chosen Nachlass-pièces sans personnes, the performance devised by Stefan Kaegi and Dominic Huber, created by Rimini Protokolle and produced by the Théâtre Vidy-Lausanne 2016.

6 For a deeper understanding of the topic, see among others: L. Aimo, Mimesi della natura e ballet d'action: per un'estetica della danza teatrale, Pisa, Fabrizio Serra, 2012; A. Cascetta, European Performative Theatre. The issues, problems and techniques of crucial masterpieces, London-New York, Routledge, 2019. 
In the auditorium of the theater there are eight small rooms, elegantly built out of bare wood. The rooms converge on an elliptical space below a ceiling that figuratively represents the world. Eight punch clocks at the top of the doorways leading into the rooms guide the entrances and exits of small groups of a dozen people. Everything proceeds slowly, fluidly, with an increasing intensity of concentration. Within each room, for a few minutes we can 'encounter' the legacy of the person to whom the room is dedicated. These are people that the theatre company, during preparations for the work, chose among the many consulted. Each for different reasons felt death was close and for some motive they wished in some way to anticipate it. For this reason they agreed to be involved in the procedure devised by the authors of the dramaturgical project. After visiting each room, the spectators converge in a central space, a sort of waiting room. In each of the rooms we can sense their presence-absence through recorded voices, objects, images: a soft white sweater, photographs, significant pieces of furniture, tools, scientific instruments related to their daily lives. The people present in their legacies are: a female ambassador of the European Union to Africa; a secretary whose dream was destroyed by multiple sclerosis; a Turkish merchant who had emigrated to Switzerland many years ago; an engineer with a passion for parachute jumping; a former director of the department of neurosciences in Lausanne; an expert in cerebral degeneration; a retired watchmaker with a passion for photography; a young father who is keen on fly fishing, but suffers from an incurable disease that will soon separate him from his daughter: and an elderly German couple, very close-knit, who recall with sorrow, disapproval and regret the ideology that caused World War II and their short-sightedness that prevented them from immediately recognising its brutality and delayed their opposition to it.

Their characters are different, but above all they differ in their attitudes, composing the mosaic that Western culture and European philosophical thought have built up over the centuries to solve what it regards as the 'problem' of humanity and the greatest violation of the idea of humanity acquired by the centuries of classicalChristian-Renaissance-Enlightenment thought, founded on the core of the individual-subjectivity-person.

In the natural world, death marks the rhythm of life without breaking the continuity of the species, but it becomes a problem in human life in relation to the destiny of the single person as an individual. For humanity, death is not generally accepted as a natural event, but rather a source of anguish, of which the history of thought, particularly in the West, has in itself sought the reasons and meaning outside the natural order. Even the materialist tradition that originated in Democritus and Epicurus, flowing into a certain modern scientific thought, has not abolished the problem. The composition of the group of absent-present bodies takes this perspective into account with the Muslim Turk and the neuroscientist... 
Death remains a violation of the person-body with its organic unity, its complex construction, its relationships, its links with time and history: the Nachlass of the title.

The performance by Rimini Protokoll speaks of this.

It speaks of the sign impressed by the individual body-person, of the trace that binds him or her to others and endures karstically through time (being, beingthere, being-with), the exact opposite of the narcissistic mask, 'diabolic' (that which divides), that I mentioned in the previous paragraph.

The theme, here as there, is welded in a skilfully homologous way with the expressive solution.

Several audiences are actively involved, in small groups so as not to disperse and weaken the intensity of the dramaturgical experience. They are ejected from their usual passivity, induced to look each other in the face, to acknowledge one another and establish some relationship beyond the usual one of sitting side by side. It is a meditation on a crucial theme that has a personal, philosophical resonance, but also a historical and civil significance (there is an open allusion to the possibility of deciding one's own death in Switzerland).

Persons-bodies are called on to overcome the feelings of awkwardness and to reveal themselves, assisted by a dramaturgy that interweaves and metabolises solutions old and new. One is the processional form, a great archetype of medieval and Renaissance theatricality and ritual, today being revived by many artists. (Think of William Kentridge and his beautiful and moving Shadow Procession, which I was reminded of when I saw the luminous planosphere with dots that appear and disappear on the ceiling in Nachlass.) Another is the open letter, yet another the journalistic investigation or the message posted on the social network. But the cement is the human voice with its eternal power of evocation.

Real people are involved in a form of theatre that, in keeping with the current macro-trend of performative theatre, is closer to presence than representation, to the truth of testimony than to mimesis of character. Yet this does not prevent it from touching on the depth of meaning of the symbolic and the harmony of form proper to art. And there is no lack of humour that lucidly unmasks and perhaps thinks of Beckett. Are these "experts" (so Rimini-Protokoll calls its actor-characters) made to come to terms with their illusion? Wanting to live at all costs? Is it narcissism? Is it human arrogance? Or is it holding hands across the generations to construct the human?

What remains of the living body?

Traces. 


\section{Bibliography}

Cascetta Annamaria, European Performative Theatre, London and New York, Routledge 2019.

Cascetta Annamaria, Melchiorre Virgilio (eds.), Il corpo in scena, Milano, Vita e Pensiero 1983.

Courtine Jean-Jacques (sous la direction de), Histoire du corps. 3. Les mutations $d u$ regard. Le XX siècle, Paris, Les Éditions du Seuil, 2006.

Fourier Anne, Gilardi Paola, Andreas Härter, Maeder Claudia (eds.), Rimini Protokoll, "Mimos 2015", Bern, Berlin, Peter Lang 2014.

Melchiorre Virgilio, Corpo e persona, Genova, Marietti 1987.

Annamaria Cascetta

\section{Ciała i scena między obecnością i brakiem}

\section{Streszczenie}

Teatr europejski podejmuje problemy naszych czasów z coraz większym zaangażowaniem i odpowiedzialnością, zarówno na poziomie egzystencjalnym, jak i społecznym.

Jednocześnie bada i eksperymentuje z językiem dostosowanym do komunikacyjnego i estetycznego horyzontu naszych czasów.

W eseju, który inauguruje w piśmie serię poświęconą studiom nad teatrem, analizuję dwa cieszące się uznaniem na arenie międzynarodowej dzieła. Są one emblematyczne zarówno pod względem tematyki (ciało, śmierć, pamięć), do której kontemplacji zapraszają czytelnika, jak i pod względem eksperymentalnej techniki, poprzez którą angażują odbiorców.

Analizowane spektakle to La Merda włoskiego twórcy, Cristiana Ceresoli, w interpretacji Silvii Gallarani oraz Nachlass szwajcarsko-niemieckiego artysty, Stephena Kaegi, stworzony dla berlińskiej grupy Rimini Protokoll.

Słowa kluczowe: teatr, ciało, śmierć, pamięć 


\title{
Bodies on stage between presence and absence
}

\author{
Summary
}

European theatre engages with the problems of our time with ever greater commitment and responsibility, crucial both on the existential and the social level.

At the same time it is researching and experimenting with a language suited for the communicative and aesthetic horizon of our age.

This essay, intended to inaugurate in this journal a series of critical studies of the theatre, analyses two works, highly successful internationally, emblematic both by their theme (the body, death, memory) on which they invite the spectators to reflect and the experimental technique through which they involve audiences.

The performances analysed are "La Merda" by the Italian Cristian Ceresoli, interpreted by Silvia Gallarani and "Nachlass" by the Swiss-German Stephen Kaegi for the Berlin group Rimini Protokoll.

Keywords: theatre, body, death, memory

Annamaria Cascetta, profesor Historii Teatru i Sztuk Performatywnych. Uczyła na Wydziale Sztuk i Filozofii na Università Cattolica del Sacro Cuore i na Università degli studi w Mediolanie. Członek komitetu wykonawczego Accademia Ambrosiana i członek komitetu wykonawczego CIT (Centro di cultura e iniziativa teatrale) "Mario Apollonio", które założyła w 2008 r. i którym kierowała do roku 2013. Współdyrektor Canone teatrale europeo/Canon of European Drama. Autor i redaktor wielu książek na temat XVII- i XVIII-wiecznego teatru włoskiego i XX-wiecznego teatru europejskiego (np. Modern European Tragedy, London, New York, Dehli, Anthem Press 2014).

Annamaria Cascetta, full professor of History of Theatre and Performing Arts. She was teacher in the Faculty of Arts and Philosophy and Università Cattolica del Sacro Cuore and at Università degli studi in Milan (Italy). She is member of the executive committee of the international Accademia Ambrosiana (area Borromean Studies) and member of the executive committee of CIT (Centro di cultura e iniziativa teatrale) "Mario Apollonio" which she founded in 2008 and direted until 2013. She is co-director of the series Canone teatrale europeo/Canon of European Drama. She is author or editor of numerous books on the seventeenth and eighteenth-century Italian theatre and twentieth-century European theatre (see Modern European Tragedy, London, New York, Dehli, Anthem Press 2014). 